\title{
Model Regressi Penggunaan Rangkaian Sosial Pendidikan
}

Nur Amalina Shamsudin, Baharuddin Aris, Mohd Shafie Rosli*

Fakulti Pendidikan, Universiti Teknologi Malaysia, 81310 UTM Johor Bahru, Johor, Malaysia

*Corresponding author: shafierosli@utm.my

\begin{abstract}
The purpose of this study is to study the frequency of social network usage among educational technology master degree students at Universiti Teknologi Malaysia as well as studying its usage factors. This study uses survey research design, questionnaire is used as research instrument and 70 research samples involved through simple random sampling technique. Usage factors has been divided into four factors which are technological factor, exposure factor, content factor and social influence factor. Research instrument reliability is 0.88 . Multiple regression backward solution procedure technique used in constructing the educational social network usage regression model. The research findings suggest that physical development should not been focused, however infrastructure development for the purpose of supporting ubiquitous learning is recommended.
\end{abstract}

Keywords: Social network. regression model

\begin{abstract}
Abstrak
Tujuan kajian ini adalah untuk mengkaji kekerapan penggunaan rangkaian sosial dalam kalangan pelajar sarjana teknologi pendidikan di Universiti Teknologi Malaysia serta mengkaji faktor-faktor penggunaannya. Kajian ini menggunakan rekabentuk kajian tinjauan, soal selidik digunakan sebagai instrumen kajian dan 70 orang sampel kajian dilibatkan menggunakan kaedah persampelan rawak mudah. Faktor penggunaan dibahagikan kepada empat faktor iaitu faktor teknologi, faktor pendedahan, faktor kandungan serta faktor pengaruh sosial. Kebolehpercayaan instrumen kajian adalah 0.88. Ujian regresi pelbagai kaedah prosedur penyelesaian ke belakang digunakan bagi membangunkan model regressi penggunaan rangkaian sosial pendidikan. Hasil dapatan kajian mencadangkan pembangunan fizikal tidak perlu difokuskan, namun pembangunan infrastruktur bagi tujuan menyokong pembelajaran ubiquitous adalah disarankan.
\end{abstract}

Kata kunci: Rangkaian Sosial, Model Regressi

(C) 2016 Penerbit UTM Press. All rights reserved

\subsection{PENDAhuluan}

Halaman rangkaian sosial seperti Facebook dan Twitter berkembang pesat bermula dari awal tahun 2010. Penggunaan Facebook telah mendapat tempat yang signifikan dalam kalangan komuniti persekitaran digital (De Oliveira \& Huertas, 2016; Cheung, Chiu \& Lee, 2011). Facebook sebati dalam kehidupan masyarakat, malahan akses pemasaran barangan kepada pengguna kini dapat dilaksanakan dengan berkesan melalui Facebook (Ng, 2016). Secara hipotetikal, Facebook kini adalah alatan utama dalam masyarakat seperti mana perlunya masyarakat kepada telefon bimbit. Perkembangan teknologi telah memperlihatkan Twitter sebagai pusat komunikasi yang efektif. Sebagai contoh, semasa bencana ribut Haiyan di Filipina, Twitter digunakan sebagai medium komunikasi (Takahashi, Tandoc \& Carmichael, 2015). Hladik dan Stetka (2015) melaporkan bahawa Twitter telah menjadi sumber berita kepada masyarakat. Keadaan ini mencetuskan kewujudan komuniti digital yang bersifat lebih terbuka dan membolehkan interaksi berlaku melangkaui batasan geografi. Justeru, dapat disimpulkan rangkaian sosial adalah sebahagian daripada kehidupan masyarakat pada masa kini.

Penggunaan rangkaian sosial yang kerap dan pada frekuensi yang tinggi telah mendorong pengintegrasian rangkaian sosial ke dalam persekitaran pendidikan. Pendekatan ini dikenali sebagai rangkaian sosial pendidikan. Pelajar berinteraksi dalam rangkaian sosial pendidikan dengan domain pembelajaran jauh lebih dominan dari domain interaksi sosial (Rap \& Blonder, 2015). Ini membuktikan, pelajar mempunyai kawalan semasa menggunakan rangkaian sosial pendidikan menjadikan ianya sebagai medium pembelajaran yang berpotensi tinggi. Frekuensi interaksi yang tinggi menunjukkan korelasi positif dengan prestasi pembelajaran pelajar, malah, kualiti kerja mereka yang kerap berinteraksi dalam rangkaian sosial pendidikan juga didapati lebih baik (Putnik et al. 2015). Walau bagaimanapun, masih kurang kajian dijalankan mengenai apakah faktor yang mendorong pelajar untuk menggunakan rangkaian sosial?

Berdasarkan kajian rintis yang telah dilaksanakan, didapati aplikasi rangkaian sosial pendidikan lebih kerap dilaksanakan di peringkat pendidikan tertier (Mouakket, 2015; Tian, 2015; Ab Rahim, Abidin \& Abidin, 2015; Abdullah \& Said, 2015). Faktor ekonomi dan persekitaran pendidikan tertier yang lebih mesra telefon pintar dan gadget memungkinkan pelaksanaan rangkaian sosial pendidikan. Kajian terkini pula memberikan fokus kepada aplikasi rangkaian sosial pendidikan di peringkat lanjutan tertier iaitu pascasiswazah (Al-Debei, AlLozi \& Papazafeiropoulou, 2013; Ab Rahim, Abidin \& Abidin, 2015). Pada masa yang sama, di Universiti Teknologi Malaysia, kursus Sarjana Teknologi Pendidikan turut mengaplikasikan rangkaian sosial pendidikan (Abdullah \& Said, 2015). Faktor kebolehan mudah alih (Kwon, Park \& Kim, 2014; Pee, Maksum \& Norizan, 2014), faktor pendedahan (Helou \& Ab. Rahim, 2014), faktor kandungan (Frey et al. 2013; Balali et al. 2013) dan faktor sosial (Glynn, Huge \& Hoffman, 2012) dikenalpasti sebagai faktor yang mempengaruhi penggunaan rangkaian sosial diperingkat pendidikan tertier dan pascasiswazah. 
Model penggunaan rangkaian sosial pendidikan oleh pelajar Sarjana Teknologi Pendidikan UTM dapat membantu para pengamal pendidikan merekabentuk rangkaian sosial pendidikan mereka. Model ini, membolehkan rangkaian sosial pendidikan digunakan secara optimum. Faktor yang tidak menyumbang kepada penggunaan rangkaian sosial pendidikan dapat dikenal pasti menggunakan model ini, faktor tersebut kemudian boleh dielakkan atau diminimumkan semasa pengaplikasian rangkaian sosial pendidikan. Faktor-faktor yang dikenal pasti menyumbang kepada penggunaan rangkaian sosial pendidikan boleh diterapkan oleh pengamal pendidikan bagi membolehkan objektif pendidikan dicapai. Apakah dia model penggunaan rangkaian sosial pendidikan oleh pelajar Sarjana Teknologi Pendidikan UTM? Oleh yang demikian, kajian ini bertujuan untuk menghasilkan model regressi penggunaan rangkaian sosial oleh pelajar Sarjana Teknologi Pendidikan UTM. Model ini membantu institusi pengajian tinggi merancang polisi pengajaran dan pembelajaran.

\subsection{OBJEKTIF KAJIAN}

i. Mengenal pasti faktor penggunaan rangkaian sosial pendidikan oleh pelajar Sarjana Teknologi Pendidikan UTM

ii. Menghasilkan model regressi penggunaan rangkaian sosial pendidikan bagi pelajar Sarjana Teknologi Pendidikan UTM

\subsection{PERSOALAN KAJIAN}

i. Apakah faktor penggunaan rangkaian sosial pendidikan oleh pelajar Sarjana Teknologi Pendidikan UTM?

ii. Apakah model regressi penggunaan rangkaian sosial pendidikan bagi pelajar Sarjana Teknologi Pendidikan UTM?

\subsection{METODOLOGI KAJIAN}

Populasi dan Sampel

Populasi adalah pelajar Sarjana Teknologi Pendidikan dari Fakulti Pendidikan UTM. Kaedah pensampelan rawak mudah digunakan dan tujuh puluh orang pelajar daripada lapan puluh tiga orang populasi disampelkan berdasarkan kepada jadual Krejcie dan Morgan. (1970).

\section{Instrumen dan Pengukuran}

Soal selidik merupakan hasil kombinasi beberapa kajian lepas mengenai rangkaian sosial sepertimana yang telah dilaksanakan oleh Nur Amalina Shamsudin (2010). Soal selidik ini dibahagikan kepada dua bahagian iaitu Bahagian A dan Bahagian B. Bahagian A merupakan bahagian berkaitan dengan maklumat demografi sampel menggunakan kaedah senarai semak Thurtson. Bahagian B mengandungi 20 item mengenai faktor penggunaan rangkaian sosial menggunakan skala Likert dengan 1 adalah sangat tidak setuju, 2 sebagai tidak setuju, 3 mewakili sederhana setuju, 4 adalah setuju dan 5 bagi menzahirkan perspektif sangat setuju. Empat konstruk telah dibentuk iaitu faktor teknologi, faktor pendedahan, faktor kandungan dan faktor pengaruh sosial. Pemilihan konstruk dibuat berdasarkan kepada hasil kajian rintis yang telah dilakukan. Nilai min 0 sehingga 1.67 ditafsirkan sebagai tidak setuju, 1.68 sehingga 3.34 sebagai sederhana setuju dan 3.35 sehingga 5 sebagai setuju.

Kesahan dan Kebolehpercayaan Instrumen

Instrumen telah disahkan oleh pakar. Kebolehpercayaan adalah Alpha Cronbach $=0.88$ menggunakan kaedah internal consistency .

\subsection{DAPATAN KAJIAN}

Faktor Penggunaan Rangkaian Sosial Pendidikan

\section{Faktor Teknologi}

Jadual 1 merupakan analisis faktor teknologi terhadap penggunaan rangkaian sosial pendidikan. Lima item digunakan untuk mengkaji faktor teknologi.

Jadual 1 Faktor teknologi

\begin{tabular}{|c|c|c|c|c|c|c|c|c|}
\hline \multirow{2}{*}{ Item } & \multirow{2}{*}{ Perkara } & \multicolumn{5}{|c|}{ Tahap (\%) } & \multirow{2}{*}{ Min } & \multirow{2}{*}{ S.P } \\
\hline & & 1 & 2 & 3 & 4 & 5 & & \\
\hline 1 & $\begin{array}{l}\text { Mudah untuk diakses di mana sahaja membuatkan saya suka } \\
\text { menggunakan rangkaian sosial. }\end{array}$ & 1.40 & 7.10 & 17.10 & 42.90 & 31.40 & 3.96 & .95 \\
\hline 2 & $\begin{array}{l}\text { Saya boleh mengakses rangkaian sosial melalui pelbagai perkakasan } \\
\text { seperti mobile phone. }\end{array}$ & 1.40 & 10.00 & 12.90 & 45.70 & 30.00 & 3.93 & .98 \\
\hline 3 & $\begin{array}{l}\text { Saya masih dapat melayari rangkaian sosial walaupun sering } \\
\text { diselenggara. }\end{array}$ & 1.40 & 5.70 & 17.10 & 55.70 & 20.00 & 3.87 & .85 \\
\hline 4 & $\begin{array}{l}\text { Walaupun kemudahan wireless tidak disediakan di semua tempat, ia tidak } \\
\text { menyukarkan saya untuk melayari rangkaian sosial. }\end{array}$ & 4.30 & 5.70 & 17.10 & 52.90 & 20.00 & 3.79 & .98 \\
\hline \multirow[t]{2}{*}{5} & $\begin{array}{l}\text { Saya dapat melayari rangkaian sosial walaupun dengan kelajuan internet } \\
\text { yang perlahan. }\end{array}$ & 4.30 & 8.60 & 17.10 & 60.00 & 10.00 & 3.63 & .94 \\
\hline & Purata & & & & & & 3.84 & .94 \\
\hline
\end{tabular}


Nilai min faktor teknologi secara purata adalah 3.84, dan boleh ditafsirkan sebagai setuju. Item 1 didapati memiliki nilai min paling tinggi dan item 5 sebagai paling rendah. Semua item ditafsirkan dipersetujui oleh sampel. Teknologi ubiquitous didapati mendorong penggunaan rangkaian sosial dalam kalangan sampel (item 1, 2 dan 4).

\section{Faktor Pendedahan}

Jadual 2 merupakan analisis faktor pendedahan.

Jadual 2 Faktor pendedahan

\begin{tabular}{|c|c|c|c|c|c|c|c|c|}
\hline \multirow{2}{*}{ Item } & \multirow{2}{*}{ Perkara } & \multicolumn{5}{|c|}{ Tahap (\%) } & \multirow{2}{*}{ Min } & \multirow{2}{*}{ S.P } \\
\hline & & 1 & 2 & 3 & 4 & 5 & & \\
\hline 6 & $\begin{array}{l}\text { Saya dapat menggunakan rangkaian sosial kerana } \\
\text { arahan penggunaannya jelas. }\end{array}$ & 4.30 & 4.30 & 17.10 & 52.90 & 21.40 & 3.83 & .96 \\
\hline 7 & $\begin{array}{l}\text { Penggunaan rangkaian sosial meliputi pelbagai } \\
\text { bidang. }\end{array}$ & .00 & 1.40 & 20.00 & 41.40 & 37.10 & 4.14 & .79 \\
\hline 8 & $\begin{array}{l}\text { Pensyarah turut menggunakan rangkaian sosial } \\
\text { untuk berkomunikasi dengan pelajar. }\end{array}$ & 2.90 & 4.30 & 25.70 & 40.00 & 27.10 & 3.84 & .97 \\
\hline 9 & $\begin{array}{l}\text { Pendedahan seperti iklan untuk menggunakan } \\
\text { rangkaian sosial dijalankan secara meluas. }\end{array}$ & .00 & 7.10 & 7.10 & 58.60 & 27.10 & 4.06 & .80 \\
\hline 10 & $\begin{array}{l}\text { Pihak universiti juga menggunakan rangkaian } \\
\text { sosial untuk memudahkan komunikasi dengan } \\
\text { pelajar. }\end{array}$ & 1.40 & 7.10 & 30.00 & 38.60 & 22.90 & 3.74 & .94 \\
\hline & Purata & & & & & & 3.92 & .89 \\
\hline
\end{tabular}

Nilai min faktor pendedahan secara purata adalah 3.92, ditafsirkan sebagai setuju. Item 7 didapati memiliki nilai min paling tinggi dan item 10 sebagai paling rendah. Semua item ditafsirkan dipersetujui oleh sampel. Pendedahan secara tidak komersial (item 6, 8 dan 10) tidak mempengaruhi penggunaan sebaik pendedahan secara komersial (item 9).

\section{Faktor Kandungan}

Lima item telah digunakan bagi mengkaji faktor kandungan. Jadual 3 merupakan data yang diperolehi dari item yang berkenaan.

Jadual 3 Faktor kandungan

\begin{tabular}{|c|c|c|c|c|c|c|c|c|}
\hline \multirow{2}{*}{ Item } & \multirow{2}{*}{ Perkara } & \multicolumn{5}{|c|}{ Tahap (\%) } & \multirow{2}{*}{ Min } & \multirow[t]{2}{*}{ S.P } \\
\hline & & 1 & 2 & 3 & 4 & 5 & & \\
\hline 11 & $\begin{array}{l}\text { Saya boleh berbincang mengenai semua perkara } \\
\text { selain pendidikan dalam rangkaian sosial. }\end{array}$ & 1.40 & 4.30 & 8.60 & 52.90 & 32.90 & 4.11 & .84 \\
\hline 12 & $\begin{array}{l}\text { Rangkaian sosial membolehkan saya memuatnaik } \\
\text { video dan gambar kesukaan saya. }\end{array}$ & 2.90 & 5.70 & 20.00 & 42.90 & 28.60 & 3.89 & .99 \\
\hline 13 & $\begin{array}{l}\text { Aplikasi seperti tag dan event yang terdapat dalam } \\
\text { rangkaian sosial memudahkan penyebaran } \\
\text { maklumat. }\end{array}$ & 1.40 & .00 & 12.90 & 48.60 & 28.60 & 3.89 & .99 \\
\hline 14 & $\begin{array}{l}\text { Pelbagai aplikasi tambahan yang menarik terdapat } \\
\text { dalam rangkaian sosial seperti permainan } \\
\text { membuatkan saya suka menggunakannya. }\end{array}$ & 1.40 & 7.10 & 15.7 & 44.30 & 31.40 & 3.97 & .95 \\
\hline 15 & $\begin{array}{l}\text { Melalui notifikasi yang dihantar dalam rangkaian } \\
\text { sosial, saya boleh mengetahui perkembangan } \\
\text { terkini yang berlaku antara rakan-rakan. }\end{array}$ & 1.40 & 2.90 & 8.60 & 48.60 & 38.60 & 4.20 & .83 \\
\hline & Purata & & & & & & 4.05 & .88 \\
\hline
\end{tabular}

Pada puratanya, nilai min bagi konstruk faktor kandungan adalah 4.05. Ianya menunjukkan bahawa faktor kandungan dipersetujui oleh sampel sebagai faktor penggunaan rangkaian sosial. Item faktor kandungan mempunyai nilai min yang lebih tinggi berbanding item bagi faktor lain sebelum ini seperti dalam Jadual 1 dan Jadual 2. 


\section{Faktor Pengaruh Sosial}

Jadual 4 menunjukkan data deskriptif bagi konstruk faktor pengaruh sosial. Lima item telah dibina bagi mengkaji konstruk ini.

Jadual 4 Faktor pengaruh sosial

\begin{tabular}{|c|c|c|c|c|c|c|c|c|}
\hline \multirow{2}{*}{ Item } & \multirow{2}{*}{ Perkara } & \multicolumn{5}{|c|}{ Tahap (\%) } & \multirow{2}{*}{ Min } & \multirow{2}{*}{ S.P } \\
\hline & & 1 & 2 & 3 & 4 & 5 & & \\
\hline 16 & $\begin{array}{l}\text { Ajakan daripada rakan-rakan membuatkan saya } \\
\text { menggunakan rangkaian sosial. }\end{array}$ & 1.40 & 2.90 & 17.10 & 45.70 & 32.90 & 4.06 & .87 \\
\hline 17 & $\begin{array}{l}\text { Melalui rangkaian sosial, saya berpeluang } \\
\text { mengenali rakan baru. }\end{array}$ & 1.40 & 4.30 & 7.10 & 50.00 & 37.10 & 4.17 & .85 \\
\hline 18 & $\begin{array}{l}\text { Saya dapat bersosial bersama rakan sambil } \\
\text { berbincang tentang pembelajaran. }\end{array}$ & 1.40 & 2.90 & 11.40 & 52.90 & 31.40 & 4.10 & .82 \\
\hline 19 & $\begin{array}{l}\text { Saya memperolehi pelbagai maklumat tambahan } \\
\text { melalui link dan iklan yang terdapat dalam } \\
\text { rangkaian sosial. }\end{array}$ & 2.90 & 1.40 & 10.00 & 50.00 & 35.70 & 4.14 & .87 \\
\hline 20 & $\begin{array}{l}\text { Rangkaian sosial memudahkan saya } \\
\text { berkomunikasi dengan rakan-rakan. }\end{array}$ & 2.90 & .00 & 8.60 & 47.10 & 41.40 & 4.24 & .84 \\
\hline & Purata & & & & & & 4.14 & .85 \\
\hline
\end{tabular}

Nilai min bagi konstruk pengaruh sosial adalah paling tinggi berbanding konstruk lain dan item-item pengaruh sosial juga didapati mempunyai nilai min yang lebih tinggi dan lebih tinggi berbanding item bagi konstruk faktor kandungan. Rumusannya, faktor pengaruh sosial adalah faktor paling utama penggunaan rangkaian sosial oleh sampel.

\section{Penggunaan Rangkaian Sosial}

Jadual 5 memaparkan data penggunaan rangkaian sosial oleh sampel. Sebanyak sembilan item telah dibina bagi menguji penggunaan rangkaian sosial oleh sampel.

Jadual 5 Penggunaan Rangkaian Sosial

\begin{tabular}{|c|c|c|c|c|c|c|c|c|}
\hline \multirow{2}{*}{ Item } & \multirow{2}{*}{ Perkara } & \multicolumn{5}{|c|}{ Tahap (\%) } & \multirow{2}{*}{ Min } & \multirow{2}{*}{ S.P } \\
\hline & & 1 & 2 & 3 & 4 & 5 & & \\
\hline 21 & $\begin{array}{l}\text { Saya gemar berbual bersama rakan melalui } \\
\text { aplikasi chat dalam rangkaian sosial. }\end{array}$ & .00 & 10.00 & 15.70 & 32.90 & 41.40 & 4.10 & .99 \\
\hline 22 & $\begin{array}{l}\text { Saya suka berinteraksi dengan rakan-rakan } \\
\text { melalui mesej dalam rangkaian sosial. }\end{array}$ & 1.40 & 5.70 & 15.70 & 42.70 & 34.30 & 4.03 & .93 \\
\hline 23 & $\begin{array}{l}\text { Saya sering memberi komen pada profil rakan- } \\
\text { rakan saya dalam rangkaian sosial. }\end{array}$ & 1.40 & 7.10 & 21.40 & 35.70 & 34.30 & 3.94 & .99 \\
\hline 24 & $\begin{array}{l}\text { Saya suka mengemas kini profil saya dalam } \\
\text { rangkaian sosial. }\end{array}$ & .00 & 15.70 & 21.40 & 41.40 & 21.40 & 3.69 & .99 \\
\hline 25 & $\begin{array}{l}\text { Saya sering mengemas kini gambar saya dalam } \\
\text { rangkaian sosial. }\end{array}$ & .00 & 14.30 & 21.40 & 40.00 & 24.30 & 3.74 & .99 \\
\hline 26 & $\begin{array}{l}\text { Saya gemar memuat naik video kegemaran saya } \\
\text { untuk dikongsi bersama rakan-rakan. }\end{array}$ & .00 & 17.10 & 30.00 & 38.60 & 14.30 & 3.50 & .94 \\
\hline 27 & $\begin{array}{l}\text { Saya sering menerima mesej notifikasi yang } \\
\text { memberitahu apa perkembangan terbaru yang } \\
\text { berlaku pada rakan saya dalam rangkaian sosial. }\end{array}$ & 1.40 & 11.40 & 27.10 & 28.60 & 21.40 & 3.67 & .99 \\
\hline \multirow[t]{2}{*}{28} & $\begin{array}{l}\text { Saya suka menggunakan aplikasi tag untuk } \\
\text { berkongsi sesuatu dengan rakan-rakan. }\end{array}$ & .00 & 8.60 & 28.60 & 41.40 & 21.40 & 3.76 & .89 \\
\hline & Purata & & & & & & 3.84 & .96 \\
\hline
\end{tabular}

Didapati kegunaan utama rangkaian sosial dalam kalangan sampel adalah bagi tujuan komunikasi dua hala sama ada secara synchronous atau asynchronous merujuk kepada item 21, 22 dan 23. Perkongsian video mencatatkan nilai min yang terendah. Ianya mungkin oleh kerana kekangan kelajuan Internet ataupun kemampuan kouta Internet dalam kalangan sampel.

\section{Model Regressi}

Kerangka penggunaan rangkaian sosial dibina menggunakan ujian regresi pelbagai menggunakan kaedah prosedur penyelesaian ke belakang. Rumusan model regresi adalah seperti dalam Jadual 6.

Jadual 6 Rumusan model regresi pelbagai

\begin{tabular}{cccc}
\hline $\mathbf{R}$ & $\mathbf{R}^{\mathbf{2}}$ & Adjusted $\mathbf{R}^{\mathbf{2}}$ & $\begin{array}{l}\text { Std. Error of } \\
\text { the Estimate }\end{array}$ \\
\hline .997 & .994 & .993 & 1.363 \\
\hline
\end{tabular}

Nilai $R=.997$ menunjukkan nilai korelasi yang tinggi. Nilai $R^{2}=.994$ menunjukkan variasi dalam pembolehubah bersandar yang mana $99.4 \%$ boleh diterangkan oleh kerangka yang dihasilkan. Pentafsiran mendapati $99.4 \%$ perubahan dalam pembolehubah bersandar, penggunaan rangkaian sosial adalah disebabkan oleh kombinasi pembolehubah-pembolehubah peramal iaitu Faktor Teknologi, Faktor Pendedahan, Faktor Kandungan dan Faktor Pengaruh Sosial. Jadual 7 merupakan analisis pembolehubah bersandar dan pembolehubah peramal. 
Jadual 7 Pekali regresi pelbagai

\begin{tabular}{clccccc}
\hline \multirow{2}{*}{ Model } & & \multicolumn{2}{c}{ Unstandardized Coefficients } & $\begin{array}{c}\text { Standardized } \\
\text { Coefficients }\end{array}$ & \multirow{2}{*}{ t } & Sig. \\
\cline { 3 - 5 } & & B & Std. Error & Beta & & \\
\hline \multirow{2}{*}{1} & (Constant) & 1.799 & .922 & & 1.951 & .055 \\
& Faktor Teknologi & 1.795 & .200 & .380 & 8.971 & .000 \\
& Faktor Pendedahan & 1.659 & .219 & .261 & 8.971 & .000 \\
& Faktor Kandungan & 1.223 & .453 & .196 & 2.702 & .009 \\
& Faktor Pengaruh Sosial & .916 & .239 & .179 & 3.829 & .000 \\
\hline
\end{tabular}

Keputusan ujian t (Jadual 7) memaparkan bahawa wujud hubungan yang signifikan diantara pembolehubah bersandar dan kesemua pembolehubah peramal. Data dari Jadual 7 digunakan untuk membina model seperti dalam Rajah 1.

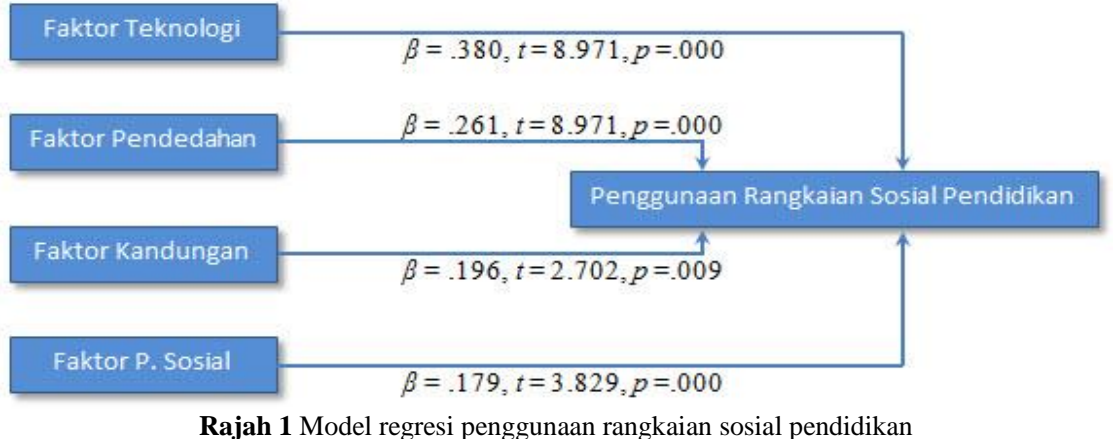

\subsection{PERBINCANGAN}

Perkara yang mungkin mengganggu kesahan model adalah bilangan sampel yang kecil. Namun, kaedah pensampelan dan jumlah sampel adalah memadai untuk menghasilkan model regresi bagi pelajar Sarjana Teknologi Pendidikan di UTM.

Teknologi ubiquitous menyumbang besar kepada penggunaan rangkaian sosial dalam kalangan sampel. Ianya sinonim dengan kebolehan untuk melakukan multitask dan kemampuan untuk multitask sangat mempengaruhi penerimaan teknologi oleh manusia (Rosli et al. 2016a). Malahan, berdasarkan hasil analisis path dan Model Persamaan Strukur didapati bahawa teknologi sememangnya merupakan faktor motivasi penggunaan rangkaian sosial dalam kalangan pelajar institusi pengajian tinggi (Rosli et al. 2016b). Infrastruktur sebagai sub-elemen faktor teknologi tidak memberikan impak yang besar kepada penggunaan rangkaian sosial pendidikan. Kemampuan teknologi ubiquitous didapati telah mengatasi keperluan kepada infrastruktur secara fizikal dan infrastruktur perkomputeran awan didapati lebih diperlukan pengguna (Seo et al. 2015). Adalah dianjurkan agar institusi pendidikan menumpukan usaha dan sumber secara kolektif ke arah membina persekitaran yang mendokong teknologi ubiquitous. Pembangunan infrastruktur fizikal perlu dikurangkan kerana tidak mempunyai pengaruh sekuat kemampuan teknologi ubiquitous. Sampel juga lebih cenderung ke arah teknologi ubiquitous berbanding teknologi mudah alih.

Pendedahan kepada rangkaian sosial pendidikan secara tidak komersial (Shin, Byun \& Lee, 2015; Pan, Vorvoreanu \& Zhou, 2014; Stambaugh, 2012) tidak memberikan kesan sehebat pendedahan secara komersial. Walaubagaimanapun, pendedahan secara komersial memberikan kesan dorongan untuk pengguna menggunakan rangkaian sosial pendidikan. Pengintegrasian rangkaian sosial pendidikan ke dalam pendidikan tertier tidak memerlukan pendedahan atau galakan dari pihak institusi. Sebaiknya, pendedahan kepada rangkaian sosial pendidikan dibuat menggunakan iklan dan promosi komersial yang sedia ada dipasaran. Ianya dapat menjimatkan kos kepada pihak institusi dan tenaga pengajar serta didapati lebih berkesan dan memberikan impak.

Faktor kandungan adalah lebih dominan berbanding faktor teknologi dan pendedahan. Rangkaian sosial telah dibangunkan untuk membolehkan interaksi secara maya berlaku. Ciri-ciri captology yang ada dalam rangkaian sosial pendidikan menjadi penarik kepada pengguna (Baharuddin et al. 2013). Fleksibiliti rangkaian sosial pendidikan untuk tidak hanya berorientasikan kepada pendidikan tetapi mampu untuk merangkumi kandungan yang pelbagai mendekatkan pengguna dengan rangkaian sosial pendidikan. Penyebaran maklumat dapat dilaksanakan dengan mudah. Kemampuan rangkaian sosial pendidikan untuk menghantar notifikasi kepada pengguna menwujudkan satu paradigma baru dalam pendidikan secara atas talian. Sekiranya kandungan rangkaian sosial pendidikan dapat dihasilkan dan disunting dengan baik, ianya lebih berimpak berbanding infrastruktur dan pendedahan secara tidak komersial. Institusi seharusnya memikirkan apakah kandungan yang dapat menarik minat pelajar. Malah, ianya lebih berkos rendah dan berkesan berbanding pembangunan infrastruktur fizikal dan pendedahan oleh pensyarah dan institusi itu sendiri.

Pengaruh sosial merupakan faktor yang paling dominan dalam penggunaan rangkaian sosial pendidikan. Komunikasi secara dua hala penting kepada para pengguna. Komunikasi secara synchronous ataupun asynchrounous mempunyai kesan yang sama. Walaubagaimanapun, pengaruh sosial tidak sentiasa membawa kesan yang positif kepada rangkaian sosial pendidikan. Ianya memungkinkan pelajar untuk hilang tumpuan semasa pembelajaran dilaksanakan. Perspektif yang positif terhadap chat, mesej dan komen memungkinkan pelajar untuk berinteraksi secara tidak akademik. Chat dan mesej mempunyai potensi yang besar sebagai faktor penghalang lantaran ianya bersifat peribadi dan tidak boleh diakses oleh guru. Ini memungkinkan pelajar berkomunikasi mengenai hal bukan akademik semasa sesi interaksi akademik. 


\subsection{IMPLIKASI DAN RUMUSAN}

Empat faktor telah dilaporkan sebagai sebab mengapa pelajar menggunakan rangkaian sosial pendidikan iaitu faktor teknologi, faktor pendedahan, faktor kandungan dan faktor pengaruh sosial. Bagi mengintegrasi rangkaian sosial pendidikan di institusi pendidikan tinggi, perkara berikut harus diambilkira:

i. Pembangunan infrastruktur fizikal yang memakan kos yang tinggi tidak memberikan impak besar terhadap penggunaan rangkaian sosial pendidikan. Kemudahan wifi, kelajuan wifi dan kemampuan komputer tidak memberikan kesan besar.

ii. Pembangunan persekitaran ubiquitous memberikan kesan yang positif. Bagi mendokong kemampuan ubiquitous, akses kepada Internet secara mudah alih amat penting diterapkan. Pihak institusi boleh menjalankan kerjasama dengan pembekal talian Internet atau ISP bagi membekalkan pelajar dengan Internet mudah alih bukan sahaja di kampus, tetapi dimana sahaja mereka berada bagi mengalakkan pengunaan rangkaian sosial pendidikan. Talian Internet yang perlahan tidak merencatkan penggunaan rangkaian sosial pendidikan kerana ianya dibina menggunakan konsep penggunaan bandwidth optimum, apa yang diperlukan oleh pelajar adalah talian Internet yang stabil dan mudah diakses.

iii. Pendedahan oleh pensyarah dan institusi sebagai pendorong penggunaan rangkaian sosial pendidikan adalah berkesan. Namun, penggunaan pengiklanan rangkaian sosial secara komersial adalah lebih berkesan. Pendedahan sepatutnya dibuat menggunakan iklan sedia ada.

iv. Kandungan dalam rangkaian sosial pendidikan jika disusun dan dimanipulasikan dengan baik akan menjadi faktor pendorong yang kuat.

v. Pengaruh sosial perlu disinergikan kearah memanfaatkan institusi dan rangkaian sosial pendidikan.

Rujukan

Ab Rahim, N. Z., Abidin, S. N. Z., \& Abidin, W. Z. (2015). The Habis of Social Networking Site (SNS) Use Among Postgraduate Students, Jurnal Teknologi, 76(1), 329-334

Abdullah, Z. \& Said, M. N. H. M. (2015). Nurturing Social-Cultural Process of Creativity in the Higher Education within Social Network Sites (SNS). Presented at 2015 International Conference on Learning and Teaching in Computing and Engineering, Taipei, 2015. Taipei.

Abdullah,Z. \& Said, M. N. H. M. (2015). Nurturing Social-Cultural Process of Creativity in the Higher Education within Social Network Sites (SNS). Dibentangkan di 2015 International Conference on Learning and Teaching in Computing and Engineering, Taipei, 2015. Taipei.

Al-Debei, M. M., Al-Lozi, E. \& Papazafeiropoulou, A. (2013). Why People Keep Coming Back to Facebook: Explaining and Predicting Continuance Participation from an Extended Theory of Planned Behaviour Perspective. Decision Support Systems, 55(1), 43-54.

Baharuddin Aris, AliReza Gharbaghi, Maizah Hura Ahmad, \& Mohd Shafie Rosli (2013). A Checklist for Evaluating Persuasive Features of Mathematics Courseware. International Education Studies, 6(9), 125-134.

Balali, A., Rajabi. A., Ghassemi, S., Asadpour, M., \& Faili, H. (2013). Content Diffusion Prediction in Social Network. Dibentangkan di 5th Conference on Information and Knowledge Technology, Shiraz, 2013. Iran.

Chen, S.-C., Yen, D. C., Hwang, M. I. (2012). Factors Influencing the Continuance Intention to the Usage of Web 2.0: An Empirical Study. Computers in Human Behavior, 28(3), 933-941.

De Oliveira, M. J., \& Huertas, M. K. Z. (2016). Factors Driving Young Users' Engagment with Facebook: Evidence from Brazil. Computers in Human Behavior, 54 (2016), 54-61.

Frey, J.-C., Ebner, M., Schon, M., \& Taraghi, B. (2013). Social Media Usage at Universities: How Should It Be Done? Dibentangkan di 9th International Conference on Web Information Systems and Technologies, Aachen, 2013. Jerman.

Glynn, C. J., Huge, M. E., \& Hoffman, L.H. (2012). All the News That's Fit to Post: A Profile of News Use on Social Networking Sites. Computers in Human Behavior, 28(1), 113-119.

Helou, A. M., \& Ab. Rahim, N. Z. (2014). The Influence of Social Networking Sites on Students' Academic Performance in Malaysia. International Journal of Electronic Commerce Studies, 5(2), 247-254.

Hladik, R. \& Stetka, V. (2015). The Power That Tweet: Social Media as News Sources in the Czech Republic. Journalism Studies, 16 (5), $60-65$.

Kwon, S. J., Park, E., \& Kim, K. J. (2014). What Drives Successful Social Networking Services? A Comparative Analysis Of User Acceptance Of Facebook And Twitter. Social Science Journal. Dalam terbitan.

Mouakket, S. (2015). Factors Influencing Continuance Intention to Use Social Network Sites: The Facebook Case. Computers in Human Behavior, 53 (11 July 2015), 102-110

Ng, M. (2016). Factors Influencing the Consumer Adoption of Facebook: A Two-Country Study of Youth Markets. Computers in Human Behavior, 54 (12 January 2016), 491-500

Nur Amalina Shamsudin (2010). Kajian Penggunaan e-Pembelajaran dan Laman Web Rangkaian Sosial dalam Kalangan Pelajar Fakulti Pendidikan Universiti Teknologi Malaysia (Disertasi Sarjana). Universiti Teknologi Malaysia.

Pan, J., Vorvoreanu, M., \& Zhou, Z. (2014). Social Media Adoption in Disaster Restoration Industry. Construction Innovation, 14(3), $346-369$.

Pee, N. C., Maksom, Z., \& Norizan, A. R. (2014). Factor Influencing The Use Of Smart Phone By Malaysian's Elderly. Journal of Theoretical and Applied Information Technology, 59(2), 421-425.

Putnik, G., Costa, E., Alves, C., Castro, H., Varela, L. \& Shah, V. (2015). Analysing the Correlation Between Social Network Analysis Measures and Performance of Students in Social Network-Based Engineering Education. International Journal of Technology and Design Education. Dalam terbitan.

Rap, S. \& Blonder, R. (2015). Let's Face(book) It: Analyzing Interactions in Social Network Groups for Chemistry Learning. Journal of Science Education and Technology. Dalam terbitan.

Rosli, M. S., Saleh, N. S., Aris, B., Ahmad, M. H., \& Salleh, S. M. (2016a). Ubiquitous Hub for Digital Natives. International Journal of Emerging Technologies in Learning, 11(2), 29-34.

Rosli, M. S., Saleh, N. S., Aris, B., Ahmad, M. N., Shamsudin, N. A., Sejzi, A. B. (2016b). E-Learning and Social Media Motivation Factor Model. International Education Studies, 9(1), 20-30.

Seo, D. B., Jeong, C.-S., Jeon, Y.,-B \& Lee, K.-H. (2015). Cloud Infrastructure for Ubiquitous M2M and IoT Environment Mobile Application. Cluster Computing, $18(2), 599-608$

Shin, H., Byun, C., \& Lee, H. (2015). The Influence of Social Media: Twitter Usage Pattern During the 2014 Super Bowl Game. International Journal of Multimedia and Ubiquitous Engineering, 10(3), 109-118.

Stambaugh, C. (2012). Social Media and Primary Commercial Service Airports. Transportation Research Record, $2325,76-86$.

Takahashi, B., Tandoc, E. C., Jr., \& Carmichael, C. (2015). Communicating on Twitter during a Disaster: An Analysis of Tweets During Typhoon Haiyan in the Philippines. Computers in Human Behavior, 50 (1), 392-398.

Tian, X. (2015). Network Domains in Social Networking Sites: Expectations, Meanings, and Social Capital. Information Communication and Society, 19(2), 188202. 